\title{
Investigating the Concerns of First-Time Distance Education Instructors
}

Halil Kayaduman ${ }^{1}$ and Turgay Demirel ${ }^{2}$

1,2 Igdir University, Turkey

\begin{abstract}
The purpose of the study is to investigate the concern developments of first-time distance education instructors using the concerns-based adoption model (CBAM). This study used stages of concern (SoC), a component of CBAM, as its theoretical framework. A descriptive case study was implemented, which focused on the adaptation processes of nine instructors lecturing for the first time via distance education. The instructors attended a two-day training, which was designed based on their initial concerns. Then instructors implemented their courses for four weeks via distance education. While the informational and personal stages (self-concerns) decreased compared to the initial findings, the consequence stage increased in intensity. However, self-concerns remained predominant in the process despite the reduction in self-concerns and increase in the consequence stage. Based on the findings, the implications for distance education and recommendations for addressing the instructors' concerns are discussed. Recommendations for alleviating the concerns of first-time distance education instructors include: the provision of ongoing concern-based interventions that incorporate technological, pedagogical, and content knowledge; providing working examples related to distance education from which instructors can learn vicariously; and encouraging collaboration among instructors.
\end{abstract}

Keywords: concerns-based adoption model, stages of concern, distance education, distance education adoption, instructors' concerns 


\section{Introduction}

Rapid advancements in technology are driving dynamic innovations across the higher education landscape. When educational institutions innovate, so too must their educators. Since people are typically resistant to change (Casey \& Rakes, 2002; Rogers, 2003), the move to Web-based education is often met with discomfort and concern from instructors asked to adapt to the changing tide.

Moving from face-to-face to distance education can be a strenuous process for instructors, as they learn unfamiliar technologies and face new pedagogical challenges (Conrad, 2004). As such, it's essential that institutions understand their instructors' concerns as they transition into new realms and provide the appropriate support necessary to facilitate this process (Evans \& Myrick, 2015; Lochner, Conrad, \& Graham, 2015; Menchaca \& Bekele, 2008). This notion is supported by Berigel (2013), who posits that instructors who receive proper support from their institutions are more likely to be successful in adopting distance education than those who do not.

As institutions moving to distance education models design their support programs, they must not simply consider the technical knowledge necessary to conduct distance education courses, but also the wider range of concerns faced by instructors as they move from an in-person to a Web-based teaching format. Having a clear understanding of the concerns that emerge throughout the distance education process and designing a support program around those concerns is likely to not only facilitate a smoother adaptation process for the instructor, but also likely to yield a more successful and sustainable implementation of distance education for institutions at large.

\section{Literature Review}

Distance education instructors should possess a wide range of skills in order to carry out their courses effectively (Dabbagh \& Bannan-Ritland, 2005). They must be subject matter and pedagogy experts; skilled evaluators, researchers, and advisors; and possess technological savvy (Bawane \&Spector, 2009; Beaudoin, 1990; Egan \& Akdere, 2005). As such, much of the responsibility for the course depends on how adeptly they can wear multiple hats (Berge, 1995).

Considering the myriad responsibilities resting on the instructors (Bawane \& Spector, 2009; Beaudoin, 1990; Berge, 1995; Egan \& Akdere, 2005), first time distance education instructors are quite likely to have a set of concerns related to the implementation process (Hall \& Hord, 2014). These concerns can influence people's decisions in structuring the course and the overall quality of their performance (Hall, 1976). Hall and George (1979) define concern as "the composite representations of feelings, preoccupations, thoughts, and considerations given to a particular issue or task" (p. 8). Ghaith and Shaaban (1999) expressed that concerns influence one's sense of self-efficacy; Wexler (2003) stated that the instructors' concerns impact their ability to successfully adapt to new educational settings. Therefore, it is critical to have a nuanced understanding of the concerns of instructors moving from face-to-face to distance education, as their concerns might have a significant impact on the overall implementation of the course.

Many factors might have an impact on the concerns of instructors switching from face-to-face to distance education. First, technological literacy is likely to be a concern for many first time distance education instructors. Specifically, instructors may have concerns around their ability to create and 
deliver content, monitor students' participation, manage virtual live classes, and assess learning outcomes online (Almarashdeh, 2016; Berigel, 2013; Carr-Chellman \& Duchastel, 2000; Erlich, ErlichPhilip, \& Gal-Ezer, 2005; Hardy, 1999; Menchaca \& Bekele, 2008). Secondly, the pedagogical knowledge of the instructors could be another critical factor influencing their concerns. Thieman (2008) stated that the indifference of students and their low participation in the course activities can cause concerns for instructors. Since the successful implementation of instruction relies primarily on an instructor's pedagogical knowledge (Berigel, 2013; Menchaca \& Bekele, 2008; Shamoail, 2005), lack of understanding about theinstructional methods and strategies that might be implemented in distance education can raise concerns for the instructors. Finally, instructors might also be concerned about the support that will be provided by their respective institutions. Directors and support staff within an organizational structure can have a positive impact on the adaptation process for the instructors (Berigel, 2013; Evans \& Myrick, 2015; Lochner et al., 2015; Menchaca \& Bekele, 2008; Weaver, Spratt, \& Nair, 2008). Although the concern factors influencing instructors' adaptation to Web-based technologies and distance education is well documented in the literature (Almarashdeh, 2016; Berigel, 2013; Carr-Chellman \& Duchastel, 2000; Erlich et al., 2005; Evans \& Myrick, 2015; Hardy, 1999; Lochner et al., 2015; Menchaca \&Bekele, 2008; Shamoail, 2005; Thieman, 2008; Weaver et al., 2008), very little is known about what the initial concerns of instructors switching from face-to-face to distance education are and how these concerns evolve in the process. To discover what these concerns are, it is necessary to investigate the instructors' adaptation to distance education from their perspective.

\section{Theoretical Framework}

The current study is based on the Stages of Concern (SoC) component of the Concerns Based Adoption Model (CBAM) (Hall, George, \& Rutherford, 1977). Many research studies use CBAM in education to understand the adaptation of people to an innovation (Borgerding, Sadler, \& Koroly, 2013; Khoboli \& O'toole, 2012). Hall and Hord (2014) describe SoC as the personal side of change and define it as a developmental pattern of emotions to an innovation. This theoretical framework divides developing concerns into "stages," as to enable an understanding of how individuals move from one concern to another: while one concern decreases, another concern increases. The stages in the model are: Unconcerned, Informational, Personal, Management, Consequence, Collaboration, and Refocusing (George, Hall, \& Stiegelbauer, 2006). In the Unconcerned stage or Stage 0, individuals indicate little or no concern toward using innovation. In the Informational stage or Stage 1, individuals indicate general understandings and ask for more information about using the innovation. In the Personal stage or Stage 2, individuals are more concerned about their abilities and adequacies to fulfill the innovation's demands. In the Management stage or Stage 3, individuals focus on the issues related to managerial problems such as time and efficiency, and in the Consequence stage or Stage 4, individuals consider the learning outcomes as a result of innovation's implementation. In the Collaboration stage or Stage 5, individuals seek collaboration to enhance the effectiveness of using innovation. Lastly, in the Refocusing stage or Stage 6, individuals are concerned about revising the way they use the innovation in order to increase its effectiveness or to replace it with an alternative.

The instructors in the current study started to lecture their courses via distance education for the first time due to a decision made by their university's senate. Determining the instructors' concerns and addressing their needs in order to facilitate their change process was thus a crucial consideration to ensure that the new courses were implemented successfully. 


\section{Purpose of the Study}

The purpose of the present study is to investigate the initial concerns of the instructors switching from face-to-face to distance education and assess how their concerns evolve throughout the process of implementation. The following research questions guided the study:

1. What are the initial concerns of the instructors switching from face-to-face to distance education?

2. How did the concerns of the instructors evolve in the process of implementation after a concerns-based intervention?

\section{Method}

This is a mixed methods case study (Merriam, 1998), which focuses on the adaptation processes of nine instructors lecturing for the first time via distance education. The reason for selecting a mixed methods case study is to provide a rich analysis of the topic. We collected both quantitative and qualitative data using interviews and questionnaires to ensure that the study encompassed a broad perspective.

\section{Participants}

The participants in the study at hand are instructors from the same university in Turkey who have no previous experience lecturing via distance education. Four of the instructors teach English Language courses, three teach History of the Revolution of the Turkish Republic, and two teach Turkish Philology courses. Teaching these courses is the main responsibility of these instructors, all of whom hold permanent positions at the university. Seven instructors have their master's degree and four instructors are still in pursuit of their postgraduate education in their fields. Their face-to-face teaching experiences range from 2 to 32 years. Up to now, they have managed all their courses successfully. These instructor characteristics are illustrated in Table 1 . The instructors have previously implemented their courses face-to-face and their switch to distance education was a result of a senate decision. We, as the director and deputy director of Distance Education Research and Application Center, who hold PhDs in Educational Technology, had no relationship to the courses and participants before the senate decision. All instructors have computers and smartphones connected to the Internet and know how to use them. While they generally use computers for their jobs, they mostly use smartphones for personal purposes. The instructors' self-reported competence of using technology for their courses is illustrated in Table 2. 
Table 1

The Characteristics of Instructors

\begin{tabular}{lccc}
\hline Field & $\mathrm{n}$ & Age & Teaching experience \\
\hline English language & 4 & $\begin{array}{c}31(\mathrm{M}), 32(\mathrm{~F}), \\
42(\mathrm{M}), 46(\mathrm{M})\end{array}$ & $2,9,18,20$ \\
$\begin{array}{l}\text { The history of the revolution of the } \\
\text { Turkish Republic }\end{array}$ & 3 & $\begin{array}{c}38(\mathrm{~F}), 39(\mathrm{M}), \\
57(\mathrm{M})\end{array}$ & $13,10,32$ \\
Turkish Philology & 2 & $38(\mathrm{M}), 44(\mathrm{M})$ & 8,22 \\
\hline
\end{tabular}

Note. $\mathrm{n}=$ Number of instructors. Age and teaching experience represented in years. $\mathrm{F}=$ female, $\mathrm{M}=$ male.

Table 2

The Competence of Instructors for Using Technology in Their Courses

\begin{tabular}{llc}
\hline & $\mathrm{n}$ & $\%$ \\
\hline Creating videos & 1 & 11 \\
Creating PowerPoint presentations & 6 & 67 \\
Creating Pdf files & 5 & 56 \\
Creating Word documents & 8 & 89 \\
Creating Excel files & 3 & 33 \\
Creating audio files & 1 & 11 \\
Editing image files & 3 & 33 \\
Attending online forums & 3 & 33 \\
Attending webinars & 1 & 11 \\
Uploading files to the Internet & 5 & 55 \\
Sending and receiving e-mails & 9 & 100 \\
\hline
\end{tabular}

Note. $\mathrm{n}=$ Number of instructors.

\section{Procedure}

The university senate issued a mandate that the English Language, History of the Revolution of the Turkish Republic, and Turkish Philology courses are to be implemented via distance education across the university. The distance education format allows students to access the course materials and archive records anytime and anywhere on a learning management system (LMS). Recently, most of the universities in Turkey have switched to the distance education format for these courses and successfully implemented them. Due to the increasing number of students taking these courses and the limited number of instructors, the senate of the developing Turkish university, from which study participants were selected for the study at hand, decided to move to distance education for these courses. There were no mandatory courses implemented via distance education in the university before the senate decision. Although some faculty members were used to using different LMSs for their classes, there was no common LMS used across the university. Following the senate's decision, all departments and impacted instructors were informed about the decision and a support center was established for the instructors. 
Training should be designed parallel with the developing concerns of the individuals in order to address and support their needs (Hall \&Hord, 2014). Accordingly, the present study used the SoC (Hall \&Hord, 2014) and the ADDIE model (Driscoll, 2002) to design the training based on the concerns of the instructors, differentiating our training from traditional training designs which do not incorporate instructor concerns. In order to design the training, we initially analyzed the needs of instructors using a questionnaire and an open-ended question form. We first prepared an online form to ask open-ended questions about the instructors' concerns and then administered the questionnaire as a pretest which included demographic, level of use (LoU), and stages of concern ( $\mathrm{SoC}$ ) questions to reveal instructor concerns about lecturing online. Based on the initial findings, we then designed a two-day training program consisting of two parts. The first part covered the fundamentals of distance education, the implementation process at the university, and the responsibilities of instructors and students. It also outlined the technical and pedagogical support that would be provided to instructors and students and explained the university's technological resources. The second part covered the details of using the Learning Management System (LMS) and virtual classroom. In the second training session, the instructors practiced activities related to the various facets of distance education instruction: interface, communication, uploading lesson materials, creating an assignment, forum and poll, broadcasting virtual live class, using the interactive board, and making an online test on LMS. Although the demographic questions revealed that the instructors needed to learn more about creating online materials for their lessons, we did not include it in the training since the instructors' concerns were mostly around the implementation process and technical details. While direct instruction and discussion methods were used in the first part, hands-on practices were done in the second part. Following the training, we conducted semi-structured interviews to assess the effectiveness of the training. The instructors then designed their courses and implemented the classes for four weeks on the LMS. In order to evaluate the process, we administered an online survey as a posttest and conducted semi-structured interviews again. The reason we administered the surveys and interviews after the fourth week was to relate the instructors' experiences with the training. All procedures of the study are illustrated in Figure 1.

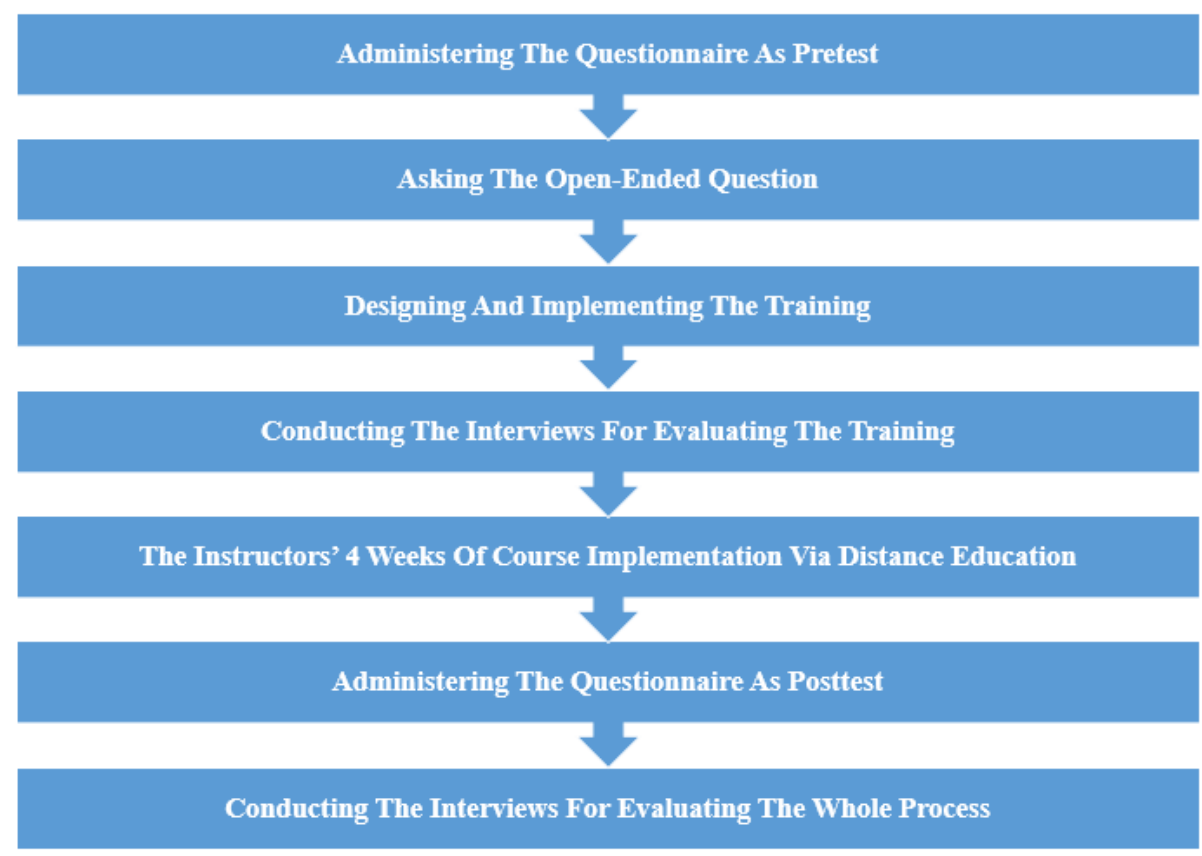

Figure 1. All procedures of the study. 


\section{Instruments}

Open-ended question. We asked to the instructors to respond to an open-ended question in order to facilitate the SoC interpretations. Newlove and Hall (1976) suggest that using an open-ended question is one of the simplest and effective ways to understand people' concerns. They recommended asking this question: "When you think about (the innovation), what are you concerned about?" (Newlove \& Hall, 1976, p. 1). We asked the same question to the instructors via an online form.

Questionnaire. The questionnaire administered in the study consists of three parts. While the first part includes demographic questions, the second part contains level of use (LoU) questions to understand the adaptation level for distance education. In the LoU section, participants select the appropriate level from the categories of Nonuse, Orientation, Preparation, Mechanical Use, Routine, Refinement, Integration, and Renewal to indicate their adaptation levels to distance education. The last part of the questionnaire involves the Turkish version of the Stages of Concern Questionnaire (SoCQ) (Baltaci-Göktalay, 2006) to measure the instructors' stages of concern toward distance education. Baltaci-Göktalay (2006) adapted the questionnaire based on the original SoCQ (George et al., 2006) and the participants were required to choose the level to which they agree on a variety of statements using a 7-point Likert scale. The overall Cronbach's Alpha coefficient of SoCQ is .87 (Baltacı-Göktalay, 2006), which is an indication of the reliability of the questionnaire.

Interviews. We designed two interviews. While we implemented the first interview right after the training to understand its effectiveness, and conducted the second interview after the four weeks of implementation to see how the instructors' concerns and level of use changed. All instructors participated in the interviews. Two experts with a doctorate degree in the College of Education examined the appropriateness of the questions and finalized the interviews.

\section{Data Analysis}

While the researchers used descriptive statistic measures to analyze the quantitative data collected via questionnaire, they followed the content analysis procedures (Miles \& Huberman, 1994; Ylldırım \& Şimşek, 2013) to analyze the qualitative data. Firstly, we transcribed the data verbatim and then followed the data reduction, data display, and conclusion drawing/ verification phases. Two experts with a doctorate degree in the College of Education checked the code and themes and found the inter-coder reliability score appropriate (90\%) (Miles \& Huberman, 1994).

\section{Validity and Reliability}

We employed different strategies to ensure the validity and reliability of the study. First, we used the triangulation strategy (Patton, 2001) to constitute the credibility. We collected both qualitative and quantitative data at different times to enable a broad perspective. Second, as for the transferability of the study, we explained the characteristics of participants, why we used the mixed methods case study and how we selected the participants as a sample. Third, while we kept the data for confirmability, the experts from the College of Education reviewed the data to certify the consistency of the study. Finally, the study was based on voluntary participation, thus helping to ensure its credibility. 


\section{Findings}

\section{Research Question 1}

We first analyzed the data gathered from the pretest to reveal the instructors' initial needs by calculating the group percentile scores (George et al., 2006) of Stages of Concern (SoC) to reveal the intensity and diversity of concerns within the group.

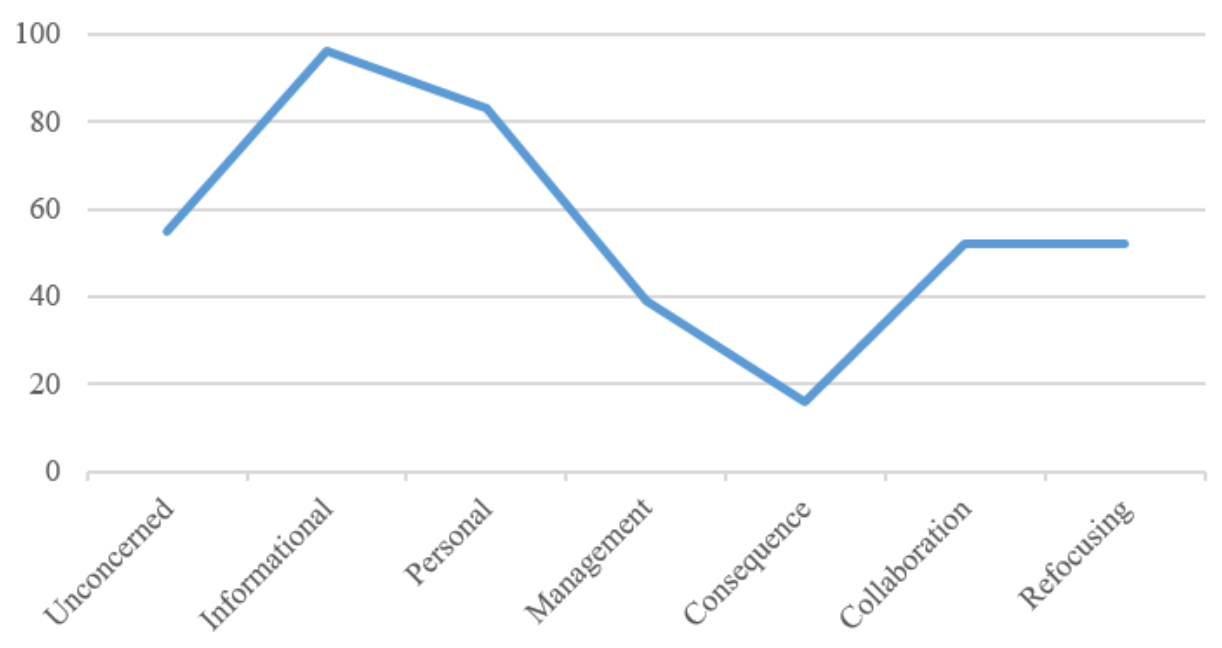

Figure 2. Group profiles of instructors in pretest.

The results suggested that, as illustrated in Figure 2, the Informational and then Personal stages were the most intense concerns among the instructors. Conversely, the Consequence stage was the least intense concern. In other words, while the instructors had considerable concerns about their ability to handle the distance education courses and displayed a strong desire to know more about distance education, they rarely thought about the effects of the distance education courses on their students.

We also analyzed the instructors' level of use (LoU) for the distance education to measure their adaptation levels. The results indicated that there were four instructors in the Orientation level, four instructors in the Preparation level, and one instructor in the Mechanical level. In other words, the instructors are mostly in the non-user category (Nonuse, Orientation, Preparation).

In order to interpret initial findings listed above on a deeper level, we also asked an open-ended question ("when you think about the implementation of your course via distance education, what are you concerned about?”) and analyzed the data. The findings are illustrated in Table 3. 
Table 3

The Descriptive Information of SoC From an Open-Ended Question

\begin{tabular}{lll}
\hline Stages of concern & $\mathrm{n}$ & $\mathrm{f}$ \\
\hline Unconcerned & 0 & 0 \\
Informational & 5 & 9 \\
Personal & 2 & 2 \\
Management & 3 & 3 \\
Consequence & 3 & 3 \\
Collaboration & 0 & 0 \\
Refocusing & 0 & 0
\end{tabular}

Note. $\mathrm{n}=$ Number of instructors, $\mathrm{f}=$ frequency of data excerpts.

As displayed in Table 3, the instructors mostly stated concerns related to the Informational stage. Moreover, they wanted to know more about the implementations that will be carried out across the university and the technical details. For example, one of the instructors expressed her concerns as follows:

We used to share a room with other instructors before. How will we carry out our courses now? Is it possible to do them at home? ... I have no experience with distance education. Will the experts advise instructors like me who will be lecturing for the first-time about the implementation process?

Another instructor stated concerns related to the use of the LMS and virtual classroom by stating "there may be problems related to the system. The instructors or students may experience issues during the lesson. We need to be fully trained about taking a video, uploading it, etc."

All in all, one can conclude that while the instructors were especially concerned with understanding the fundamentals of distance education and how the process would be implemented at the university, they were also concerned about their ability to navigate the technological challenges. Considering the findings, we designed a two-day training which covered the fundamentals of distance education, the implementation process at the university, and the details of using the LMS and virtual classroom.

\section{Research Question 2}

After carrying out the training, we conducted interviews to determine the instructors' thoughts about the effectiveness of the training. Table 4 illustrates the findings of the interview. 
Table 4

The Instructors' Thoughts About the Effectiveness of the Training

\begin{tabular}{lll}
\hline Effectiveness of the training & $\mathrm{N}$ & $\mathrm{f}$ \\
\hline Benefits of the training & 8 & 15 \\
Unnecessary details in hands-on practices & 6 & 6 \\
Providing the training earlier & 3 & 3 \\
Demanding more training & 4 & 5 \\
\hline
\end{tabular}

Note. $\mathrm{n}=$ Number of instructors, $\mathrm{f}=$ frequency of data excerpts.

According to the findings, most of the instructors $(n=8, f=15)$ found the training to be effective in addressing their concerns. Moreover, they stated that they better understood not only how the process of switching face-to-face courses to distance education courses would be implemented at the university, but also how to use the LMS and virtual classroom via hands-on practices. For example, one of the instructors noted: "The first part of the training helped us to understand the whole process. In the second part, we got enough knowledge about how to use the system. I think I could say that my concerns decreased."

Additionally, the instructors emphasized the importance of not being given too much detail in handson practices $(n=6, f=6)$ and of providing the training a few months before the semester $(n=3, f=3)$. They also recommended ongoing training to supplement the initial training $(n=4, f=5)$. One instructor articulated: "I think some of the parts were complicated for me at the beginning. It was not necessary to learn everything at this stage; maybe some additional things could be addressed over time in the future." Another instructor said "My only suggestion is that it would be more beneficial for us, if it is possible, to provide ongoing training."

All in all, while the instructors found the training helpful for lowering their concerns about using the system and helping them to understand the implementation process at the university, they wanted ongoing training that was more specific to their needs.

After the four weeks of implementation, we administered a questionnaire as a posttest to see how their concerns changed in the process of instructing courses. The group percentilescores (Georgeet al., 2006) of SoC were calculated and represented as comparative results in Figure 3. 


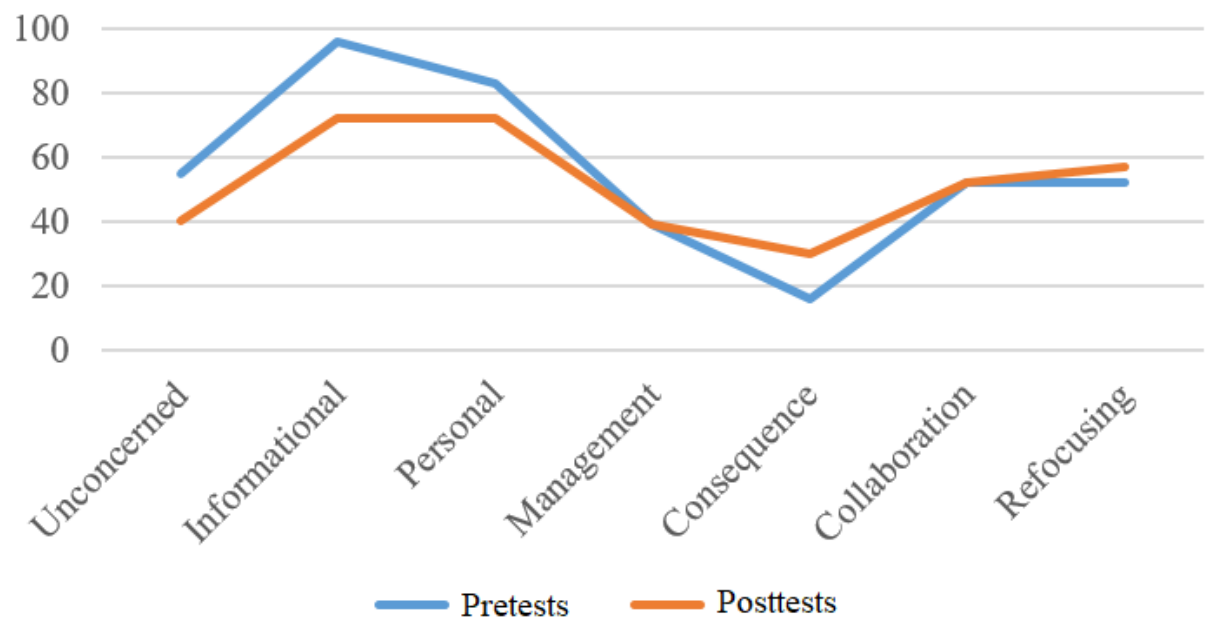

Figure 3. Group profiles of instructors in pretest and posttest.

The results indicated that while the Informational and Personal stages diminished, the Consequence stageincreased in intensity. Although theintensity of Informational and Personal stages decreased, they remained higher than the other stages. Moreover, it is clear that the instructors became more concerned about the effects of the distance education courses on their students as the courses progressed.

In addition to the SoC profiles, we analyzed the instructors' level of use for the distance education again. As one can see in Table 5, all instructors moved up one or two levels. For example, while four instructors were at the Preparation level in the pretests, they switched to the upper levels in the posttests. In total, the instructors identified as being at the Routine and Mechanical levels for LoU in the posttests.

Table 5

The Instructors' Level of Use in Pretest and Posttest

\begin{tabular}{clcc}
\hline \multirow{2}{*}{ Level of use } & Pretest & Posttest \\
\cline { 3 - 4 } Non-user & 0. Nonuse & $\mathrm{n}$ & $\mathrm{n}$ \\
\hline \multirow{3}{*}{ User } & 1. Orientation & 4 & 0 \\
& 2. Preparation & 4 & 2 \\
& 3. Mechanical & 1 & 2 \\
& 4a. Routine & 0 & 4 \\
& 4b. Refinement & 0 & 0 \\
& 5. Integration & 0 & 0 \\
& 6. Renewal & 0 & 0 \\
\hline
\end{tabular}

Note. $n=$ Number of instructors.

Following the posttest, we conducted the final interview with the instructors to see how the instructors' concerns and level of uses changed after the training and four weeks of implementation. Table 6 illustrates the findings of the interview. 
Table 6

The Instructors' Concerns and Level of Uses After Four Weeks of Implementation

\begin{tabular}{lll}
\hline Instructors' concerns and level of uses & $\mathrm{n}$ & $\mathrm{f}$ \\
\hline Sufficient level of use & 6 & 6 \\
Personal - Time and energy commitment & 5 & 6 \\
Personal - Increased confidence in distance education & 3 & 3 \\
Consequence - Learning outcomes & 5 & 8 \\
Demanding pedagogical and technological training & 6 & 8
\end{tabular}

Note. $\mathrm{n}=$ Number of instructors, $\mathrm{f}=$ frequency of data excerpts.

According to the findings, most of the instructors $(n=6, f=6)$ see their level of use to be sufficient for implementing distance education courses. For example, one of the instructors said that "Of course, as I use the systems more and gain additional information, I think I'll reach a better level of use. I think I have enough knowledge for the moment."

Additionally, most of the instructors $(\mathrm{n}=5, \mathrm{f}=6)$ stated that implementing their courses via distance education is helpful in terms of their time and energy commitment. A number of the instructors $(n=3$, $\mathrm{f}=3$ ) also expressed an increased confidence level concerning their ability to implement distance education courses. One of the instructors explained:

I think the process went well. I can present the information more concisely. My ability to lead an online course and self-efficacy increased. I was initially worried about doing an online course. Now, my ability to prepare and present online course materials improved.

On the other hand, the instructors also emphasized their concerns for the Consequence stage. In other words, most of the instructors $(n=5, f=8$ ) pointed out that the learning outcomes of students may not befully achieved due to the students' need for personalized instruction, and due to their lowengagement with course materials. One of the instructors stated: "We used to receive feedback from the students while lecturing face-to-face and revise the materials based on their needs. When we implement the classes now, we do not understand whether the students grasp it or not."

Lastly, most of the instructors ( $\mathrm{n}=6, \mathrm{f}=8$ ) demanded more training about pedagogical and technical aspects of implementing their courses. One of the instructors stated: "We might be provided support related to new approaches or instructional methods and strategies that could make distance education more effective."

In summary, the need analysis indicated that instructors were mostly concerned about the implementation process at the university and their abilities to handle the various technological aspects of distance education courses. Based on the findings, we designed a two-day training. While the instructors found the training helpful for lowering their concerns, they demanded ongoing training more specific to their needs. After the four-week implementation process, the concern stages of Informational and Personal diminished and the Consequence stage increased in intensity. All instructors moved up one or two levels in terms of LoU. The interview data supported the findings that the instructors grasped the implementation process and increased their self-efficacy for implementing 
distance education courses. They started to be more concerned about the learning outcomes of students and demanded more training about pedagogical and technical aspects of implementing their courses.

\section{Discussion}

The current study investigated the concerns of the instructors moving from face-to-face to distance education. We first determined the instructors' initial concerns and then designed a two-day training based on their concerns. After the four weeks of course implementation, we explored how their concerns evolved in the process. The initial findings revealed that the instructors' intense concerns were at Informational and Personal stages suggesting the instructors were interested in learning more about the details of using innovation, and that they were uncertain about the demands of the innovation and their roles with it (Hall \& Hord, 2014). George, Hall, and Stiegelbauer (2006) also stated that nonusers' concerns generally lie within the awareness, informational, and personal stages. Since the instructors lectured online for the first time in the current study, this finding is not surprising, as intense concerns at Informational and Personal stages indicate that the instructors want to learn more about distance education and how it will affect them personally. The initial findings also indicated that the least intense level of concern was at the Consequence stage, illustrating that the instructors did not intensely consider the effects of distance education on their students (Hall \& Hord, 2014) because their concerns were more related to being nonusers and considering the effects of implementation on themselves.

Hall and Hord (2014) expressed that training should be designed based on the developing concerns of the learners rather than paralleling with the professors' concerns. The instructors stated that the twoday training we designed was supportive for them and lowered their initial concerns. Following the training, the instructors implemented their courses online for four weeks and, accordingly, their concerns evolved as illustrated in Figure 3. The Informational and Personal stages(self-concerns) decreased in intensity. Since the successful experience reduced the intensity of their self-concerns (a pattern also suggested by George et al., 2006; Hall \& Hord, 2014), one can conclude that the training and subsequently the instructors' four weeks of implementations were successful at lowering the intensities of self-concerns and facilitating the instructors' adaptation process to distance education.

Despite the reduction in the intensity of self-concerns, these concerns remained predominant and the instructors demanded more technical and pedagogical training. The instructors' predominant selfconcerns may not only be toward distance education but also toward technology adoption since distance education applications mostly rely on Web-based technologies. In this regard, the research studies in the literature express that technical and pedagogical knowledge can affect the instructors' concerns (Almarashdeh, 2016; Berigel, 2013; Shamoail, 2005). Similarly, Lochner, Conrad, and Graham (2015) also discussed the prevalence of self-concerns, noting that instructors may think about the innovations in terms of increasing administrative efficiency rather than supporting instructional activities. Therefore, the instructors in the current study might not have enough knowledge about technical issues and instructional methods and strategies that can be implemented in distance education and, accordingly, need ongoing pedagogical and technical training in their adaption process.

After four weeks of implementation following to the training (See Figure 3), the Consequence stage increased in intensity. George et al. (2006) state that individuals consider the effects of innovation on learning outcomes in this stage. In line with this, the instructors in the study at hand also showed concern about students' learning. The instructors in the study underscored that student engagement 
with distance education courses was lower than in traditional face-to-face education. Thieman (2008) expressed that low engagement of students with the course activities can cause concern for the instructors. Therefore, the increase in intensity of the Consequence stage may have been due to the low engagements of students. In addition, the Consequence stage remained the least intense concern, indicating that the instructors experience self-concerns most intensely.

\section{Conclusion and Implications}

The current study has merit for a better understanding of the concerns of instructors moving from traditional face-to-face to distance education. This study indicated that using CBAM to design support for the instructors can facilitate their adaptation process to distance education. We initially found that the instructors had intense concerns at Informational and Personal stages. Hall and Hord (2014) underlined that successful adoption to an innovation occurs when the self-concerns (Informational and Personal) were resolved by the individuals. Hence, we designed training to target the Informational and Personal stages and, accordingly, let instructors implement their courses for four weeks. The findings indicated that this approach was successful at lowering the intensity of self-concerns and facilitating the instructors' adaptation process to distance education. However, the self-concerns remained predominant despite the reduction. Supporting the instructors before and during the implementation process is critical to helping them move from self-concerns to impact concerns (Hall \& Hord, 2014; Lochner et al., 2015). Therefore, administrators or school leaders should provide ongoing training and professional support by targeting the instructors' self-concerns. Otherwise, the persistence of selfconcerns may impact the effectiveness of instructors (Al-rawajiih, Fook, \&Idros, 2010; Dunn \& Rakes, 2010). In addition to the approach used in the current study which was helpful for lowering the selfconcerns, strategies such as encouraging collaboration (Hall \& Hord, 2014) among instructors or providing working examples related to distance education from which instructors can learn vicariously (Bandura, 1977) may also decrease the self-concerns and help facilitate the adoption process.

Although the Consequence stage increased in intensity, it remained the least intense concern after the four weeks of implementation. The instructors mostly discussed the low engagement of students in this process. Since the low engagement of students can cause concerns for the instructors (Thieman, 2008), it might be critical to support the instructors regarding this aspect. For example, Carr-Chellman and Duchastel (2000) underline the importance of using synchronous and asynchronous communication in distance education courses to increase students' engagement. Therefore; as Mishra and Koehler (2006) suggested in the TPACK (Technological Pedagogical Content Knowledge) framework, incorporating technology, pedagogy, and content knowledge while designing the training might be helpful to increase the intensity of impact concerns. By doing so, the instructors can learn not only the technical details of Web-based technologies but also how to use them to support instructional activities.

Administrators, faculty members, researchers, change facilitators, or educational planners can gain insights from this study about the concerns of the instructors moving from traditional to distance education. They can facilitate the instructors' adoption to distance education through the development of specific interventions that are focused on the instructors' most intense concern stages. 


\section{Limitations and Further Research}

The current study is limited by the characteristics of the instructors and the small sample size: nine instructors in total. Hence, these factors should be considered when interpreting the findings. In this study, instructors switched to distance education as a result of a decision of the university's senate. For this reason, their concern development might be different from those instructors who switch to distance education voluntarily. Accordingly, further research should focus on the concern developments of these sort of instructors. In the scope of the study, we interpreted the group profiles of the instructors. Although we analyzed the individual profiles, we did not seeany specific patterns related to gender, age, technology competence level, or years of experience possibly because of the small sample size. Hence, further research should form a larger sample size and analyze the individual profiles of the instructors regarding these variables. In addition, we did not collect any data related to the quality of the courses, students' grades, or course evaluation reports. Therefore, further research could collect such data to probe the instructors' concern in more detail. In the present study, we measured the instructors' concerns only twice through pretest and posttest questionnaires, with the posttest being administered after the fourth weeks of implementation. Hence, further research should measure the instructors' concerns regularly to see how their concerns evolve. Finally, the instructors' concerns might also stem from difficulties with technology adoption beyond distance education. Therefore, further research is needed to investigate the instructors' concerns in terms of technology adaption. 


\section{References}

Almarashdeh, I. (2016). Sharing instructors experience of learning management system: A technology perspective of user satisfaction in distance learning course. Computers in Human Behavior, 63, 249-255. https:// doi.org/ 10.1016/j.chb.2016.05.013

Al-rawajfih, K., Fook, F. S., \& Idros, S. N. S. (2010). Stages of concern in integrating e-learning in discovery schools. Asian Social Science, 6(8), 54- 63. https:// doi.org/ 10.5539/ass.v6n8p54

Baltacı-Göktalay, Ş. (2006). Identification and resolution of concerns regarding adoption of online technologies: Challenges facing higher education in a developing country-TURKEY (Doctoral dissertation). Retrieved from ProQuest Dissertations \& Theses Global. (Order No. 3233089).

Bandura, A. (1977). Self-efficacy: Toward a unifying theory of behavioral change. Psychological Review, 84(2), 191-215. https:/ / doi.org/ 10.1037/ 0033-295X.84.2.191

Bawane, J ., \& Spector, J . M. (2009). Prioritization of online instructor roles: Implications for competency-based teacher education programs. Distance Education, 30(3), 383-397. https:// doi.org/ 10.1080/01587910903236536

Beaudoin, M. (1990). The instructor's changing role in distance education. American J ournal of Distance Education, 4(2), 21- 29. https:/ / doi.org/ 10.1080/ 08923649009526701

Berge, Z. L. (1995). The role of the online instructor/ facilitator. Educational Technology, 35(1), 2230. Retrieved from https:// www.researchgate.net/publication/238348806 The Role of the Online Instructo rFacilitator

Berigel, M. (2013). Öğretim elemanlarının uzaktan eğitim ortamlarına uyum süreçlerinin incelenmesi [Investigating adoption of instructors to distance education environment] (Doctoral dissertation). Retrieved from YÖK TEZ. (Order No. 344510).

Borgerding, L., Sadler, T., \& Koroly, M. (2013). Teachers' concerns about biotechnology education. J ournal of Science Education \& Technology, 22(2), 133-147. https:// doi.org/ 10.1007/ s10956012-9382-z

Carr-Chellman, A., \&Duchastel, P. (2000). The ideal online course. British J ournal of Educational Technology, 31(3), 229-241. https:// doi.org/ 10.1111/ 1467-8535.00154

Casey, H. B., \& Rakes, G. C. (2002). An analysis of the influence of technology training on teacher stages of concern regarding the use of instructional technology in schools. J ournal of Computing in Teacher Education, 18(4), 124- 132. https:// doi.org/ 10.1080/ 10402454.2002.10784448

Conrad, D. (2004). University instructors' reflections on their first online teaching experiences. J ournal of Asynchronous Learning Network, 8(2), 31-44. Retrieved from http:// docushare3.dcc.edu/docushare/dsweb/Get/Version9844/FacultyReflectionsTeachingOnline.pdf 
Dabbagh, N., \& Bannan-Ritland, B. (2005). Online learning: Concepts, strategies, and application. Upper Saddle River, NJ : Pearson Education.

Driscoll, M. (2002). Web-based training: Creating elearning experiences (2nd ed.). San Francisco, CA: J ossey-Bass/ Pfeiffer.

Dunn, K. E., \& Rakes, G. C. (2010). Learner-centeredness and teacher efficacy: Predicting teachers' consequence concerns regarding the use of technology in the classroom. J ournal of Technology and Teacher Education, 18(1), 57- 83. Retrieved from https:// www.learntechlib.org/primary/p/29376/

Egan, T. M., \&Akdere, M. (2005). Clarifying distance education roles and competencies: Exploring similarities and differences between professional and student-practitioner perspectives. American J ournal of Distance Education, 19(2), 87-103. https:// doi.org/ 10.1207/ s15389286ajde1902_3

Erlich, Z., Erlich-Philip, I., \& Gal-Ezer, J . (2005). Skills required for participating in CMC courses: An empirical study. Computers and Education, 44(4), 477- 487. https:// doi.org/ 10.1016/j.compedu.2004.04.010

Evans, S., \& Myrick, J . G. (2015). How MOOC instructors view the pedagogy and purposes of massive open online courses. Distance Education, 36(3), 295- 311. https:// doi.org/ 10.1080/01587919.2015.1081736

Ghaith, G., \&Shaaban, K. (1999). The relationship between perceptions of teaching concerns, teacher efficacy, and selected teacher characteristics. Teaching and Teacher Education, 15(5), 487496. https:// doi.org/ 10.1016/ S0742-051X(99)00009-8

George, A. A., Hall, G. E., \& Stiegelbauer, S. M. (2006). Measuring implementation in schools: The stages of concern questionnaire. Austin, TX: SEDL.

Hall, G. E. (1976). The study of individual teacher and professor concerns about innovations. J ournal of Teacher Education, 27(1), 22-23. https:// doi.org/ 10.1177/ 002248717602700106

Hall, G. E., \& George, A. A. (1979). Stages of concern about the innovation: The concept, initial verification, and someimplications. Retrieved from http:// www.eric.ed.gov/ contentdelivery/ servlet/ERICServlet?accno=ED187716

Hall, G. E., George, A. A., \& Rutherford, W. L. (1977). Measuring stages of concern about the innovation: A manual for the use of the SoC questionnaire. Retrieved from http:// www.eric.ed.gov/ contentdelivery/ servlet/ERICServlet?accno=ED147342

Hall, G. E., \& Hord, S. M. (2014). Implementing change: Patterns, principles, and potholes (4th ed.). Upper Saddle River, NJ : Pearson.

Hardy, J . V. (1999). Teacher attitudes toward and knowledge of computer technology. Computers in the Schools: Interdisciplinary J ournal of Practice, Theory, and Applied Research, 14(3-4), 119- 136. https:// doi.org/10.1300/J025v14n03_11 
Khoboli, B., \&O'toole, J . (2012). The concerns-based adoption model: Teachers' participation in action research. Systemic Practice and Action Research, 25(2), 137-148. https:// doi.org/ 10.1007/ s11213-011-9214-8

Lochner, B., Conrad, R.-M., \& Graham, E. (2015). Secondary teachers' concerns in adopting learning management systems: A U.S. perspective. TechTrends, 59(5), 62- 70. https:// doi.org/ 10.1007/ s11528-015-0892-4

Menchaca, M. P., \&Bekele, T. A. (2008). Learner and instructor identified success factors in distance education. Distance Education, 29(3), 231- 252. https:/ / doi.org/ 10.1080/01587910802395771

Merriam, S. B. (1998). Qualitative research and case study applications in education. San Francisco, CA: J ossey-Bass Publishers.

Miles, M. B., \& Huberman, A. M. (1994). Qualitative data analysis: An expanded sourcebook (2nd ed.). California: SAGE Publications.

Mishra, P., \& Koehler, M. J . (2006). Technological pedagogical content knowledge: A framework for teacher knowledge. Teachers College Record, 108(6), 1017- 1054. https:// doi.org/ 10.1111/j.1467-9620.2006.00684.x

Newlove, B. W., \& Hall, G. E. (1976). A manual for assessing open-ended statements of concern about an innovation. Retrieved from http:// www.eric.ed.gov/ contentdelivery/ servlet/ERICServlet?accno=ED144207

Patton, M. Q. (2001). Qualitative research \&evaluation methods (3rd ed.). Thousand Oaks, CA: Sage Publications.

Rogers, E. M. (2003). Diffusion of innovation (5th ed.). New York, NY: Free Press.

Shamoail, E. (2005). Teachers' perception and experiences in adopting "Blackboard" computer program in a Victorian secondary school: A case study (Unpublished doctoral dissertation). Victoria University, Victoria, Australia.

Thieman, G. Y. (2008). Using technology as a tool for learning and developing 21st century citizenship skills: An examination of the NETS and technology use by preservice teachers with their K-12 students. Contemporary Issues in Technology and Teacher Education, 8(4), 342-366.

Retrieved from https:// www.citejournal.org/volume-8/ issue-4-08/social-studies/ usingtechnology-as-a-tool-for-learning-and-developing-21st-century-citizenship-skills-anexamination-of-the-nets-and-technology-use-by-preservice-teachers-with-their-k-12-students

Weaver, D., Spratt, C., \& Nair, C. S. (2008). Academic and student use of a learning management system: Implications for quality. Australasian J ournal of Educational Technology, 24(1), 3041. https:// doi.org/ 10.14742/ ajet.1228

Wexler, D. H. (2003). Shifting pedagogies: Intersections of computer-supported technologies, education, and power (Doctoral dissertation). Retrieved from ProQuest Dissertations \& Theses Global. (Order No. 3081662). 
Yıldırım, A., \& Şimşek, H. (2013). Sosyal Bilimlerde Nitel Araştırma Yöntemleri [Qualitative research methods in the social sciences] (9th ed.). Ankara: Seçkin.

Athabasca

University

(9) (1) 